\title{
Geology and geotechnical investigations of part of the Anambra Basin, Southeastern Nigeria: implication for gully erosion hazards
}

Azuka Ocheli" ${ }^{*}$, Ovie Benjamin Ogbe ${ }^{2}$ and Godwin Okumagbe Aigbadon ${ }^{3}$

\begin{abstract}
Background: Geologic and geotechnical conditions of soils where Nanka and Ajali Formations outcropped in Anambra Basin, Southeastern Nigeria were investigated and accessed. This was done using detailed mapping and mechanical soil laboratory tests to unravel the genesis and continued expansion of gully erosion in the study areas.

Results: Field study revealed that gully erosions are more pronounced in the study area with poor vegetation cover and a high degree of slope steepness. Grain size analysis revealed that the soils of the Nanka Formation have an average sand content value of $90.90 \%$ (sandy) and silt content value of $3.0 \%$ (low fine portions). The plasticity index of the fine portions indicates that the soils are weak plastic, with a mean value of $5.29 \%$. The soils have an average cohesion value of $0.30 \mathrm{~kg} / \mathrm{cm}^{2}$ indicating a very weak cohesion. The soils are highly permeable; with an average value of $2.67 \times 10^{-3} \mathrm{~cm} / \mathrm{s}$. The compaction test further revealed that the soils are loosely compacted. The soils for the Ajali Formation have an average sand content value of $95.10 \%$ (sandy) and silt content value of $1.43 \%$ (low fine portions). The plasticity index of the fine portions indicates that the soils are weak plastic, with a mean value of $2.70 \%$. The soils have an average cohesion value of $0.30 \mathrm{~kg} / \mathrm{cm}^{2}$ indicating a very weak cohesion. The soils are highly permeable; with an average value of $2.70 \times 10^{-3} \mathrm{~cm} / \mathrm{s}$. The compaction test revealed that the soils are loosely compacted.

Conclusion: After field surveys and laboratory analyses, it was found that the gully erosions have been developing respectively on steep slopes and non-vegetated areas, and their genesis facilitated by the cohesionless and very permeable nature of the sandy formations. Following those key findings, it was proposed many practices (agronomic and engineering mainly) that can help mitigate the formations as well as the expansion of this very damaging hazard type. The potential implications of these gully erosion include damaging of buildings, residential houses, bridges, and roads, loss of farmland and vegetation, isolation of villages and towns, increased migration of inhabitants as well as degradation of agricultural fertile land.
\end{abstract}

Keywords: Geotechnical, Gully erosion, Plasticity index, Permeability, Compaction

\section{Background}

Gully erosion is an episode that is devastating the scenery of southeastern Nigeria and one of the most threatened global environmental hazards. The gully started in the middle of the nineteenth century, about 170 years

\footnotetext{
*Correspondence: ocheliazuka@yahoo.com

1 Department of Geological Sciences, Nnamdi Azikiwe University, Awka,

Anambra, Nigeria

Full list of author information is available at the end of the article
}

ago with the initiation and propagation of narrow channels which rapidly widened by erosion into major gullies, gorges, and canyon proportions (Egboka and Okpoko 1984). The rate of gully growth in southeastern Nigeria is estimated at 20-50 m/year (Egboka and Okpoko 1984). Over 2,800 active erosion sites comprising of over 1000 in Anambra, 300 in Imo, 500 in Abia, 500 in Enugu, and 500 in Ebonyi states were relayed by World Igbo Environmental Foundation (WIFE) (Ojukwu 2018). Gully erosion is a well-defined water-worn channel (Monkhouse and Small 
1978; Abdulfatai et al. 2014). It involves detachment and transport of soil particles by natural agents such as gravity, running water, ice mass, wind, freeze-thaw, and anthropogenic from the upland topmost units (Fernandez et al. 2003; Geleta 2011; Ashiagbor et al. 2013; Okengwo et al. 2015). This results in sediment deposit at the river networks leading to river morphological changes and reservoir sedimentation problems such as the reduction of water storing capacity of the reservoirs by blocking the porosity of the rock reservoirs (Fernandez et al. 2003; Geleta 2011; Ashiagbor et al. 2013; Okengwo et al. 2015). Based on the studies by Brice (1966) and Abdulfatai et al. (2014), gully erosion has been extended to include a drainage channel that transmits transient flow, steep side, steeply sloping or vertical head muffler with a width greater than $0.3 \mathrm{~m}$ and a depth greater than $0.6 \mathrm{~m}$. Gully development in the Moldavian Plateau of Romania was studied using the Caesium 137 technique, and it was discovered that $57 \%$ of the gullying occurred during the cold season and $43 \%$ occurred during the warm season (Ionita 2006). A gully erosion susceptibility assessment and management hazard-prone area was investigated in India using multivariate additive regression splines (MARS), flexible discriminate analysis (FDA). Random forest (RF) and support vector machine as well as field surveys (Gayen and Bai 2019). They built a gully erosion susceptibility model, which is useful for land managers and policymakers, as they initiate remedial measures and erosion hazard mitigation in prioritized areas (Gayen and Bai 2019). Geotechnical assessment of soil in erosion pronezone was carried out in Thekkumalai Mountain foot, Kanyakumari District Tamilnadu to identifying the geotechnical parameters that influence soil erodilibility, such that suitable soil stabilization can be ascertained (Subash et al. 2016). Geotechnical investigation and assessment of earthquake factors were carried out at Hurghada City, Red sea, Egypt (Ismaiel 2018) and it was discovered that the allowable bearing capacity of the investigated soils ranged from 1.5 to $2.5 \mathrm{~kg} / \mathrm{cm}^{2}$, and therefore recommended deep pile foundations in the region. Soil erosion models at Densu River Basin in Ghana using revised universal soil loss equation (RUSLE) and geographic information system (GIS) tools were developed to estimate the annual loss and found out that $88 \%$ of the basin has low erosion risk, and 6\% moderate erosion risk. They further stated that erosion risk is high at $3 \%$ and severe at $3 \%$ of the basin (Ashiagbor et al. 2013). Rainfall-runoff slope length and steepness and land cover management have been used for soil erosion modelling in southeastern Nigeria (Egboka et al. 2019). They described slope length as the distance from the source of runoff to the point where either deposition begins or runoff enters a welldefined channel that may be part of a drainage network.
The geologic setting, tectonic and upliftment, geotechnical properties of soil, mining activities, farming, deforestation, and overgrazing operations have been widely reported to be the major causes of gully erosion in southeastern Nigeria (Brice 1966; Egboka and Okpoko 1984; Igwe and Orji 2019). The Agulu-Nanka-Oraukwu gullies, Anambra State have been studied by (Egboka et al. 1983). They found out that acids are produced during oxidation and reduction in the physiochemical and weathering environment leading to erosion and gullies. Onwuemesi (1990) investigated the hydrogeophysical and geotechnical properties of soils in Nsukka and its environs and discovered that the areas were prone to gully erosion due to low plasticity and very loose compactness of the soils. Gully erosion in southeastern Nigeria: The roles of soil properties and environmental factors have been well discussed (Onwuemesi 1990). The characteristics and erodibility potentials of soils from different geologic formations in Anambra State, southeastern Nigeria has been investigated (Igwe and Egbueri 2018). The causes, consequences, and control measures of gully erosion in southeastern Nigeria have been revealed (Egboka et al. 2019). The dangers posed by gully erosion which include loss of farmland and vegetation, isolation of villages and towns as well as barren and infertile land have been well published by many scholars in scientific journals such as (Egboka et al. 1983; Egboka and Okpoko 1984; Igwe 2012; Igwe and Egueri 2018; Egboka et al. 2019) but the proper understanding of its genesis and continued expansion is relatively lacking. Also, few studies on gully erosion have been conducted at a large spatial scale because of its time demanding and challenges encountered during the studies. The differences in susceptibility to gully erosion within the sedimentary formations have not been adequately studied. The adopted methods for controlling gully erosion in southeastern Nigeria are inappropriate. This is because gully erosion continues to originate and expand in southeastern Nigeria.

These necessitated the field campaigns and mechanical soil laboratory analyses of sediments in the study areas to provide detail geological and geotechnical information on the origin and continued expansion of the erosion gully. The lithological and geotechnical characterization of sedimentary lithologies could contribute to highlighting the predisposing role of such landscape to the initiation of gully erosion hazard. The differences in susceptibility to gully erosion in the study areas will be identified. The digital elevation models (DEMs), slope maps, and land cover/land use maps will be generated from National Aeronautics and Space Administration (NASA) Shuttle Radar Topographic Mission (SRTM)$30 \mathrm{~m}$ data and displayed to show the influence of elevation, slope and land cover/land use on the genesis and 
development of gully erosion in the study areas. The results of this study shall further help in recommending designs for appropriate control and precautionary measures. To minimize and control the menace of gully erosion, the Nigerian government established Gully Erosion Control and Commission (GECC), a statutory body vest with the responsibility to prevent, manage, control, and redress erosion and for related matters in the affected States. The World Bank-assisted agency, the Nigeria Erosion and Watershed Management Project (NEWMAP) is also assisting in sustaining erosion control beyond 2021.

\section{Location and geomorphological setting of the study areas}

The study area lies in southeastern Nigeria (Fig. 1). The studied gullies on the exposed Nanka Formation fall within latitudes $06^{\circ} 02^{1} \mathrm{~N}-06^{\circ} 05^{1} \mathrm{~N}$ and longitudes $06^{\circ}$ $43^{1} \mathrm{E}-07^{\circ} 30^{1} \mathrm{E}$ (Fig. 2) in Anambra State while the studied gullies where Ajali Formation exposed falls within latitude $06^{\circ} 44^{1} \mathrm{~N}-06^{\circ} 55^{1} \mathrm{~N}$ and longitude $07^{\circ} 17^{1} \mathrm{~N}-07^{\circ} 27^{1} \mathrm{E}$ (Fig. 3) in Enugu State.

The study area is characterized by cuesta topography, plateaus, rolling plains, scarp slopes, conical and isolated hills of discontinuous resistant beds where Guinea savannah vegetation occurs. The cuesta is a long asymmetrical ridge whose crest describes a laterally inverted sigmoid
(Nwajide 2013). The isolated hills occur as ridges parallel to the main axis of the cuesta. The undulating topography, which trend in line with the geological formations that underlie it are described as erosional resistors which are left behind as the scarp face retreats westwards (Obi et al. 2001).

The climate is characterized by the Equatorial type found in Southeastern Nigeria mainly warm and humid, and of two seasons; the dry season and the rainy season. The rainy season begins in April and continues into October while the dry season runs from November to March. During the rainy season, a marked disruption in the rains occurs during August, resulting in a short period of no rains universally referred to as "August break", though, for years now, this has not been consistent in August as a result of climatic changes. The rainfall is always accompanied by an organized line of thunderstorms, heavy flooding, leaching of ions, and gully erosion. The dry season is characterized by the cold dry, dust-laden winds called "Harmattan" from the Sahara Desert. During this period, there is poor visibility and the sun is always obscured by the prevailing dust haze. The yearly annual rainfall ranges from $1200 \mathrm{~mm}$ (Iloeje, 1981) to $2500 \mathrm{~mm}$ (Ezemonye and Emeribe 2012; Egboka et al. 2019)). The relative humidity ranges from 60 to $85 \%$.

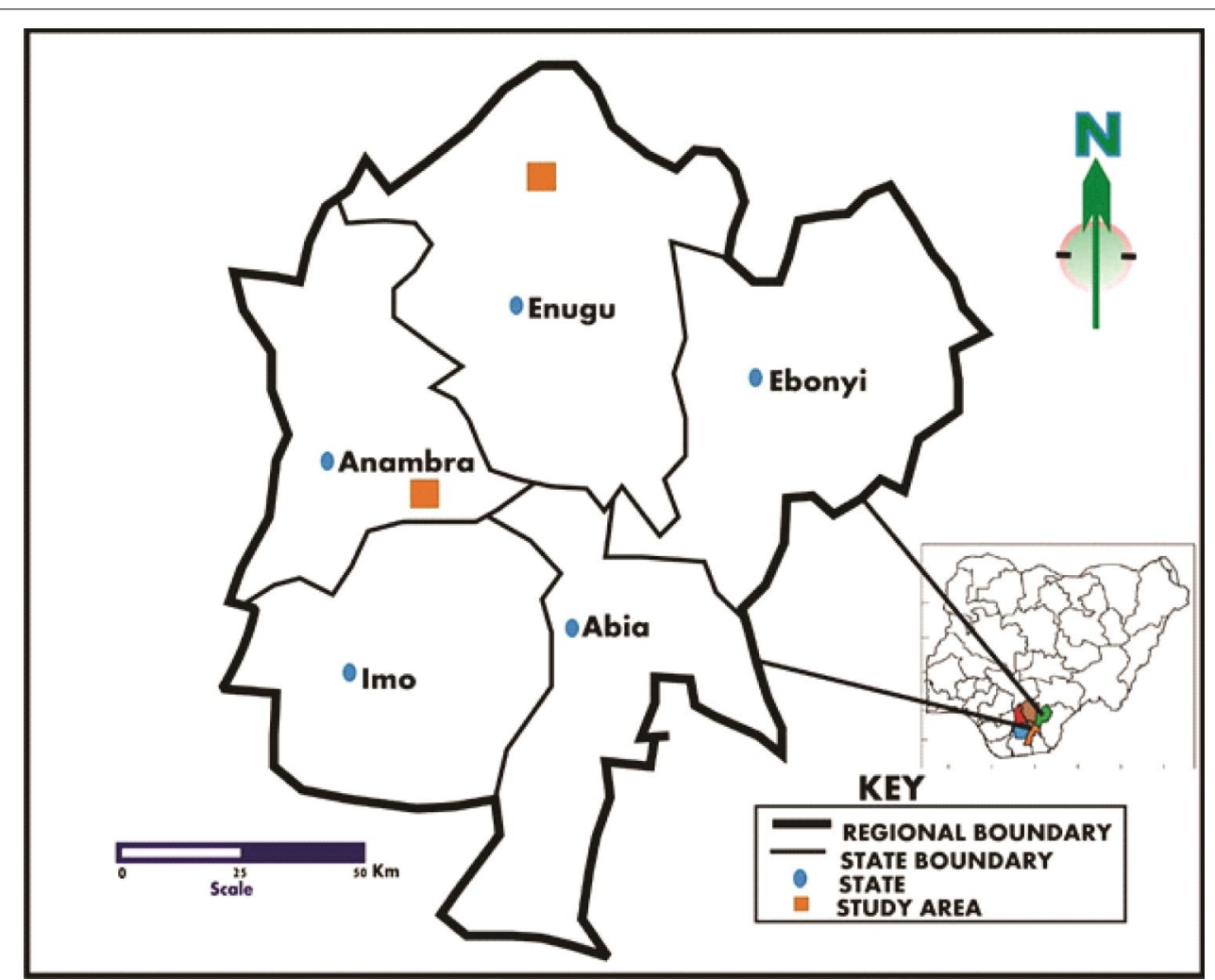

Fig. 1 Map of Southeastern Nigeria Showing the Study area (Anejionu et al. 2013; Egboka et al. 2019) 


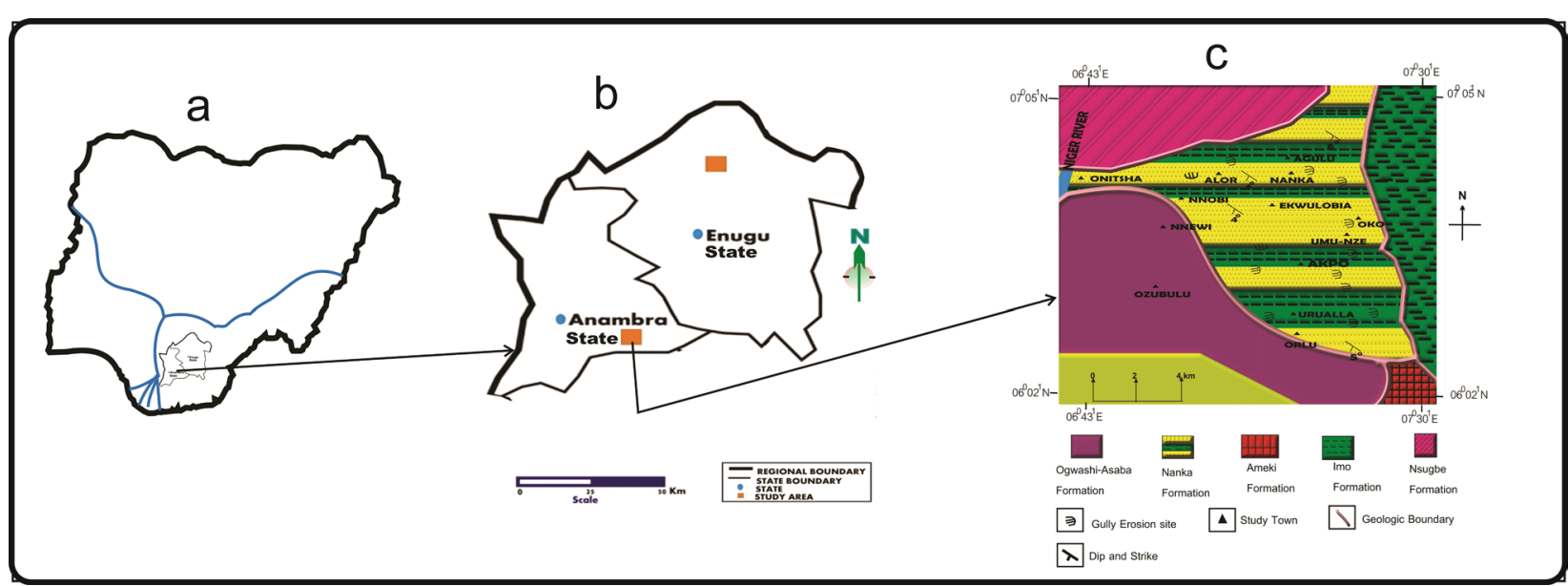

Fig. 2 a Map of Nigeria b Map of the Anambra and Enagu states showing the studies areas (Anejionu et al. 2013; Egbinki et al. 2019). c Geological Map or the study area which falls with $06^{\circ} 55^{\prime} \mathrm{N} ; 07^{\circ} 17^{\prime} \mathrm{E}-07^{\circ} 17^{\prime} \mathrm{E}$ (Nwajide 1977: Egboka and Okpoko 1984)

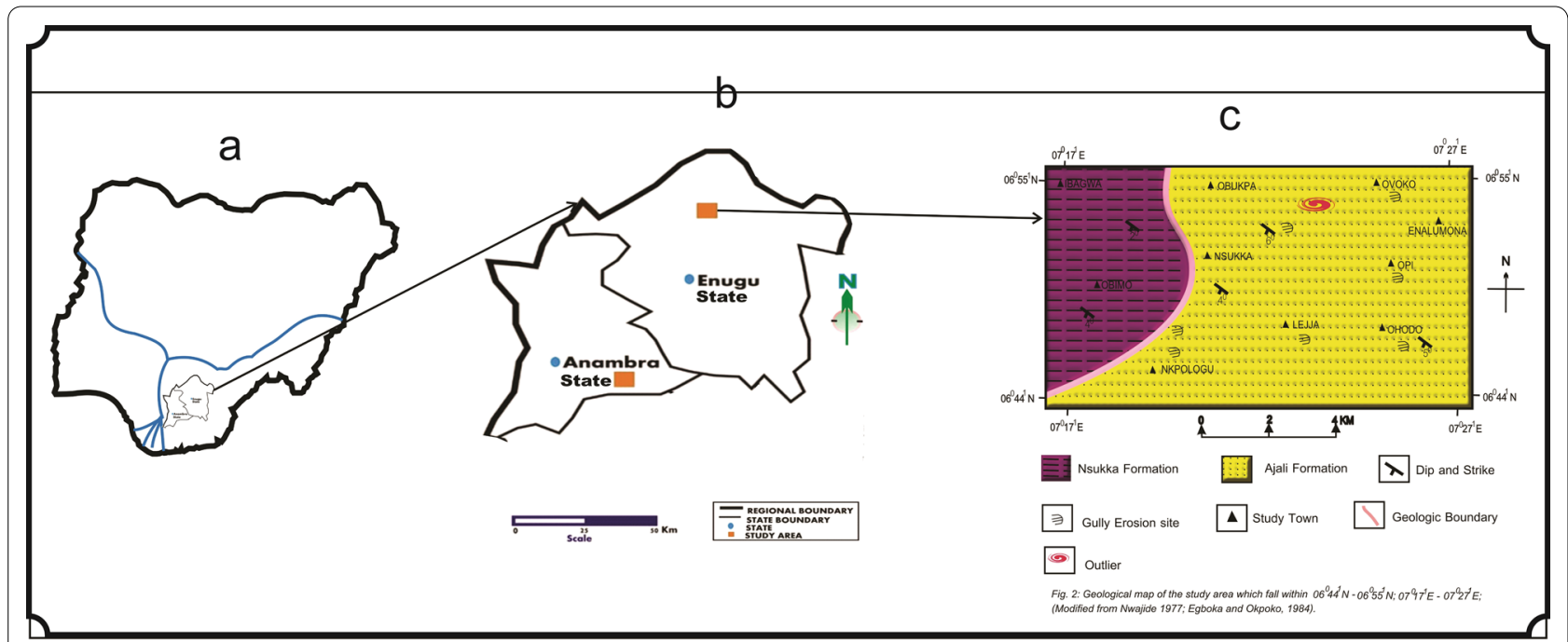

Fig. 3 a Map of Nigeria or b Map of the Anambra and Enagu states showing the studies areas (Anejionu et al. 2013; Egbinki et al. 2019). c Geological Map or the study area which falls within $06^{\circ} 02^{\prime} \mathrm{N}-07^{\circ} 05^{\prime} \mathrm{N}-06^{\circ} 43^{\prime} \mathrm{E}-07^{\circ} 30^{\prime} \mathrm{E}$ (Nwajide 1977: Egboka and Okpoko 1984)

The soils which are linked to the interior segment of the laterite soils are three types; namely alluvial, hydromorphic, and ferallitic soils. The eroded laterites are deposited on the Nsukka Surface which forms oolitic ironstone deposits. Bush fallowing and rotational subsistence farming are practiced. Some parts of the study area have been deforested which has worsened the incidence of gully erosion.

The study area is drained by several surface water networks such as River Adada, Akoru River, and the existing fresh water in the Opi-Agu in the Nsukka regions and River Iyeagu, River mamba, Oridike River, Agulu Lake, and Atama Lake in the Nanka regions. The structurally controlled drainage patterns are mostly dendritic and trellis.

\section{Geological descriptions of the study area}

Geological descriptions of the study areas have been well documented and published (Simpson 1954; Reyment 1965; Hoque and Ezepue 1977). The dominant geological formation within latitude $06^{\circ} 02^{1} \mathrm{~N}-06^{\circ} 05^{1} \mathrm{~N}$ and longitude $06^{\circ} 43^{1} \mathrm{E}-07^{\circ} 30^{1} \mathrm{E}$ is Nanka Sands which consist of successions ranging from unconsolidated to poorly consolidated sands (310m thick), thin intercalation of claystone and siltstone bands, lenses and flaser beds, cross-bedded, poorly sorted and medium to 
coarse-grained. These units are interbedded by shalesiltstone and fine sand layers $(25 \mathrm{~cm}$ thick) in a few of the gully sites. The angle of dip ranges from 4 to $6^{\circ}$ in the western direction. The Nanka sand is underlain by the thick Imo Formation of Paleocene age (Reyment 1965), and overlain by the Oligocene of Ogwashi-Asaba Formation (Reyment 1965; Adeleye and Fayose 1978) (Fig. 2). Towards the northwest part of the study area, the Nanka sand is overlain by the Nsugbe Formation of Oligocene age and underlain by the Ameki Formation of the Eocene age towards the southeastern part of the study area (Reyment 1965; Adeleye and Fayose 1978) (Fig. 2).

The geological rock system that outcropped in the study area within latitude $06^{\circ} 44^{1} \mathrm{~N}-06^{\circ} 55^{1} \mathrm{~N}$ and longitude $07^{\circ} 17^{1} \mathrm{~N}-07^{\circ} 27^{1} \mathrm{E}$ was named as the "Upper Coal Measures" and the False-Bedded Sandstone (Simpson 1954; Tattam 1944). Reyment (1965) later renamed the formation to be Nsukka Formation (Upper Maastrichtian-Paleocene) (Reyment 1965; Obi and Okogbue 2004), and the Ajali Formation (Mid- Maastrichtian) (Reyment 1965; Obi 2000; Obi and Okogbue 2004) respectively which have been used and adopted in recent studies. The lithology of the Nsukka Formation is characterized by carbonaceous shale, sandstone, siltstone, and coal. There are ridges and dome-like outliers capped by ironstones. It overlays the Ajali Formation that dips 2 to $6^{\circ}$ to the southwest direction. The Ajali Formation consists of predominantly medium to coarse, thickly friable, poorly sorted, and poorly cemented sandstones with some fine sand at the base. The topmost part of the Ajali Formation consists of reddish sands formed by the alterations owing to weathering close to the surface as a result of the presence of iron-bearing aqueous solutions (ferruginization) of the Formation (Onwuemesi 1990). The red sand is underlain by whitish sands. The whitest sandstone is more susceptible to gully erosion than the red sand since the red sand is more clayey and cohesive than the white sandstone.

\section{Materials and methods}

The methodology used in the conduct of this research work enhances this study and broadens the understanding of the dominant factors responsible for the genesis and continued expansion of the gully erosion in the study area. It helps in the identification of potential and significant adverse environmental and social impacts. Finally, it promotes the establishment of newer, improved, and effective mitigation measures.

\section{Field study}

A reconnaissance survey and detailed mapping of the study areas were carried out to identify gully sites, geological conditions, and the effect of length and steepness of the slope, land cover management, and human activities to delineate the origin and continued expansion of gully erosion in the study areas. The length and slope steepness (angle of slopes) were measured using the measuring tape and inclinometer respectively. The depth, width, and lateral extent of the gullies were measured using the measuring tape to determine the gully intensities. The use of the Global Position System (GPS) aided the assessment of land use and land cover change as well as the elevation in the study area. The digital elevation models (DEMs), slope maps, and land cover/land use maps of the study areas are generated from National Aeronautics and Space Administration (NASA) Shuttle Radar Topographic Mission (SRTM)-30m data to show the influence of elevation, slope and land use/land cover on initiation and development of gully erosion in the study areas.

The sediment samples were collected with the aid of a hand auger from twenty gully sites located in different parts of the study area where two main sedimentary Formations the Nanka Sands and the Ajali Formation outcropped. At each point of collection, samples were taken randomly from the top $(10 \mathrm{~cm})$ by removing the topsoil, gully wall, and gully floors. The sediment samples collected were carefully bagged and labelled before subjecting them to various mechanical soil laboratory tests to determine the index properties of the soils.

\section{Geotechnical analyses}

The soil index properties were determined in the laboratory by following the various methodology discussed hereunder: The plastic limit of the sediments was determined by rolling out a thread of the fine portion of soil on a flat, non-porous surface. The test was performed in accordance with procedures specified by the American Society for Testing Materials (ASTM Standard D 4318) (British standard 1990; Ishaque et al. 2010) and the British Standard Method for Testing Soils (B.S 1377-1990) (Adeleye and Fayose 1978) for civil engineering purposes. The liquid limit was measured using the Casagrande method and the procedure described by ASTM Standard 4318 (British standard 1990; Ishaque et al. 2010). The attterbergs tests were done to determine the behaviour of the soils. The grain size analysis of the sediments was carried out using the hydrometer method. This is to determine the particle size distribution of the soils. The compaction test which shows the optimum moisture content (OMC) and the maximum dry density (MDD) was carried using a protor soil compactor. The purpose is to understand the compaction characteristics of different soils with the change in moisture content. Permeability of the sediments was determined using the falling head permeability technique described by (Munch and Douglas 
1985). The purpose is to determine the hydraulic conductivity of the soils. The shear strength of the sediment was determined using a vane shear apparatus as described (Sohne 1953). The purpose is to determine the shear properties of discontinuities in soils of the study area.

\section{Results and discussion}

\section{Result of the field study}

Table 1 shows the results of slope steepness (angle of a slope) and the gully intensities in the study area. The slope is the gradient or land inclination. The standard slope descriptors (https://geographyfieldwork.com/ slopeS), a slope value $<0.3^{\circ}$ indicate flat level slope, $0.3<1.1^{\circ}$ depict nearly level, $1.1<3^{\circ}$ indicate very gentle slope, $3<5^{\circ}$ indicate gentle slope, $5<8.5^{\circ}$ indicate moderate slope, $8.5<16.5^{\circ}$ indicate strong slope, $16.5<24.0^{\circ}$ depict very strong slope, $24<35.0^{\circ}$ indicate extreme slope, $35<45.0^{\circ}$ indicate steep slope, $>45.0^{\circ}$ indicate a very steep slope. Based on the results obtained (Table 1), compared with the standard slope descriptors (https://geographyf ieldwork.com/slopeS), the degree of steepness of the gullies in the Nanka and Ajali Formations ranges from strong slopes to a very steep slope. The generated slope maps of the study areas from NASA SRTM-30 m data are displayed (Figs. 4, 5). The results obtained and the generated slope maps reveal an increase in speed and volume of the overland flow, rate of particle detachment as well as transportation of soil particles. It depicts that gully erosion is more pronounced in areas with high steepness. This finding agrees with the finding of Igwe (2015) who found that gullies with steeper slopes have higher erodibility potentials than flat ones. A reconnaissance and intensive field surveys of the study areas reveals the long length and steepness of the slope, the gully intensities which vary from low to a very high degree of erosion (Table 1), the elevation of the study areas which ranges from $<250$ to $\geq 450 \mathrm{~m}$ (Table 1 ). The generated digital elevation models of the study areas from NASA SRTM-30 m data are displayed (Figs. 6, 7) as well as the generated land cover/ land use maps from NASA SRTM -30 m, which includes water resources, built-up, road network, gully area, vegetation/derived savannah and farmland (Figs. 8, 9), contributed to the origin and continued expansion of gully erosion in the study areas. It was also observed that some of the areas have a long hilly slope which increases the amount of cumulative runoff and the steepness of the slope. This increases the velocities of the runoff and exposes surface pores of the land which eventually enhances the initiation and propagation of gully erosion. The prevalence of gully erosion in the study areas also includes human activities such as bush burning, agricultural, overgrazing, deforestation, and deliberate refusal to plant/replanting of trees, faulty road constructions and drainage systems as well as nonchalant attitude of the affected community people. The Nanka Sands comprising of sequences ranging from unconsolidated to poorly consolidated sands (310 $\mathrm{m}$ thick), thin intercalation of claystone and siltstone bands, lenses, and poorly sorted and medium to coarse-grained. These units are inter-bedded by shale and fine sand layers $(25 \mathrm{~cm}$ thick) in a few of the gully sites. The Ajali Formation comprising of predominantly medium to coarse, thickly friable, very poorly sorted to poorly sorted, and poorly cemented sandstones with some fine sand at the base. The topmost part of the Ajali Formation consists of reddish sands.

\section{Result of the geotechnical analyses}

Table 2 reveals the results of soil analysis carried out on soil samples from gully sites of the Nanka sands in the study area. The liquid limit (LL) ranges from 26.80 to $36.70 \%$ with a mean value of $30.23 \%$, plastic limit (PL) ranges from 20.30 to $28.40 \%$ with a mean value of $24.94 \%$. The plasticity index (PI) which is a measure of the plasticity of the soil is determined by the difference between the liquid limit and the plastic limit and the value ranges from 3.30 to $8.30 \%$ with a mean value of $5.29 \%$. The sands and silts content range from 86.0 to $96.0 \%$ with a mean value of $90.9 \%$ and $1.0-5.0 \%$ with a mean value of $3.0 \%$ respectively which coincides with the research work by Obiadi et al. (2014) and Igwe and Egbueri (2018). The compaction which shows optimum moisture content $(\mathrm{OMC})$ and the maximum dry density (MDD) ranges from 8.60 to $11.80 \mathrm{mg} / \mathrm{m}$ with a mean value of 10.62 and $1.40-2.00 \mathrm{mg} / \mathrm{m}$ with a mean value of 1.68. The shear strength of the soil is the result of friction and interlocking of particles and possibly cementation or bonding at the particles (Surendra and Sajeev 2017). The shear strength parameters are the cohesion and the friction angle. The cohesion value obtained varies from 0.23 to $0.43 \mathrm{~kg} / \mathrm{cm}^{2}$ with a mean value of $0.30 \mathrm{~kg} / \mathrm{cm}^{2}$. The shear angle of internal friction ranges from $24.0^{\circ}$ to $32.0^{\circ}$ with an average value of $24.7^{\circ}$. The shear strength enhances the initiation of gully erosion by encouraging overland flows. According to Surendra and Sajeev (2017), plasticity index $(\mathrm{PI})=0$ indicate sand, non-plastic, and non-cohesive, $>0<7$ indicate sand/silt, low plastic and partly cohesive, 7-17 indicate silt/clay, medium plastic, and cohesive and $>17$ indicate clay, high plastic and cohesive. The angle of shearing resistance $<28^{\circ}$ indicates very loose compaction, $28-30^{\circ}$ indicates loose, $30-36^{\circ}$ suggests medium compaction, $36-41^{\circ}$ indicates dense compaction, and $>41^{\circ}$ indicates very dense compaction (Surendra and Sajeev 2017). Table 2 shows that the soils in the gully sites of the Nanka Formation are low plastic which signifies poor cementing and insufficient binding materials suggesting a high susceptibility to gully erosion 


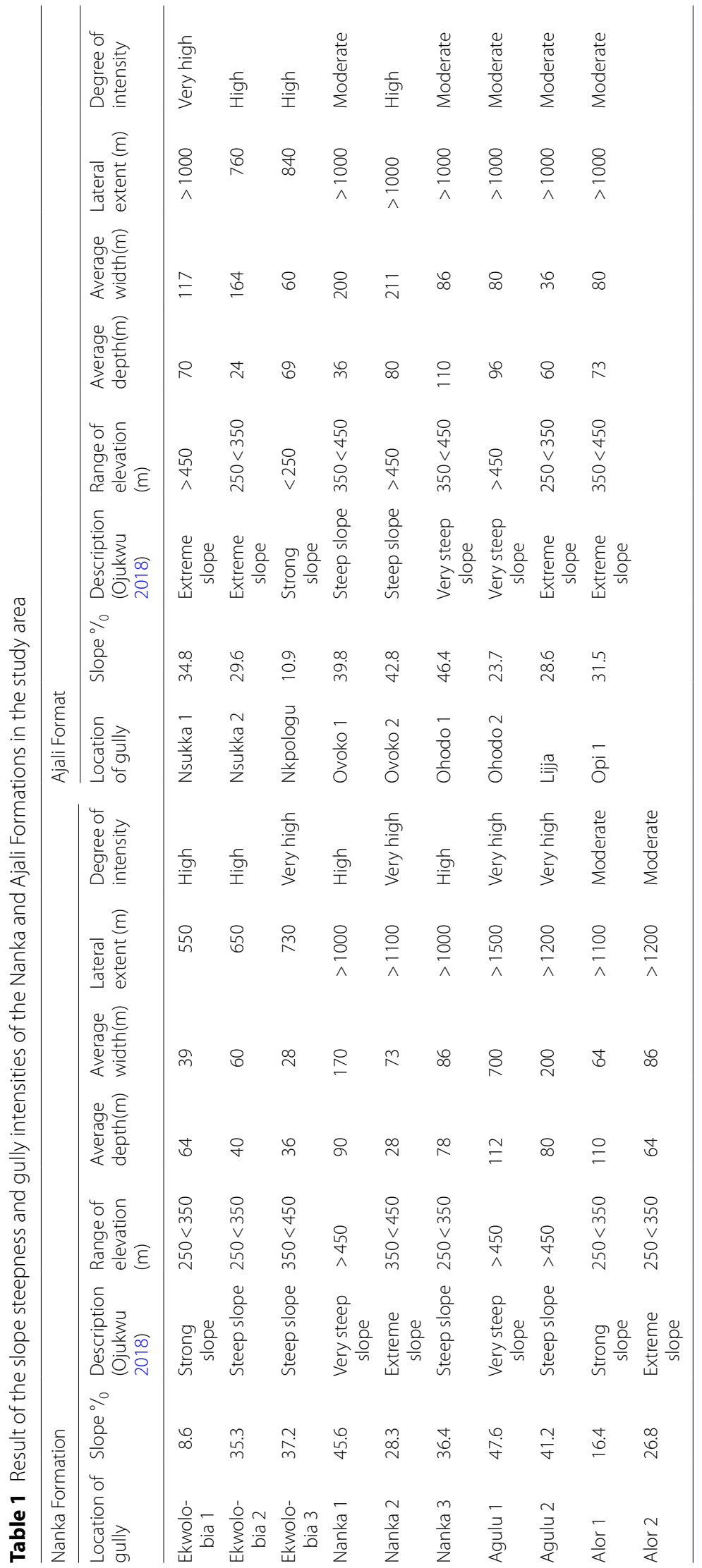




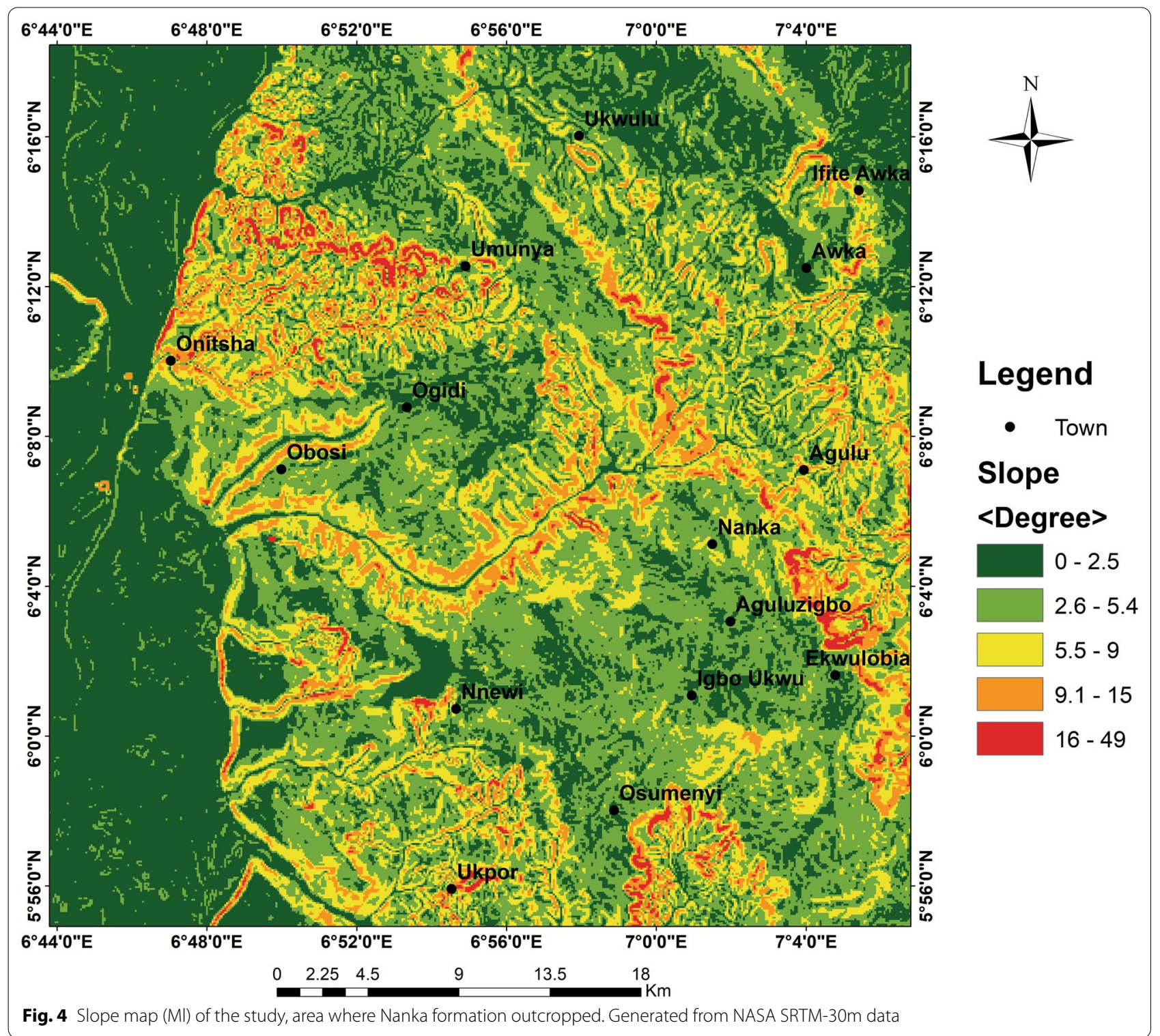

and high instability. The low moisture content indicates a high capacity for water retention during rainfall. The low value of cohesion and angle of internal friction results in soil cracking. Highly sandy with low silt content and very loose compaction reveals a very loose lithology. The values obtained for hydraulic conductivity ranges from (2.1$3.2) \times 10^{-3} \mathrm{~cm} / \mathrm{s}$ with a mean value of $2.67 \times 10^{-3} \mathrm{~cm} / \mathrm{s}$ suggesting high permeability. Based on the U.S. Bureau of Reclamation and revealed by (Surendra and Sajeev 2017), soils are classified as (i) Impervious: k (Coefficient of permeability) less than $10^{-6} \mathrm{~cm} / \mathrm{s}$, (ii) Semi-pervious: $\mathrm{k}$ between $10^{-6}$ and $10^{-4} \mathrm{~cm} / \mathrm{s}$ and (iii) Pervious: $\mathrm{k}$ greater than $10^{-4} \mathrm{~cm} / \mathrm{s}$. From the values obtained (Table 2), it shows that the soils are highly permeable suggesting high infiltration rates thereby giving rise to high flow velocities, high seepage pressure, and high internal erosion potentials (Okengo et al. 2015). Table 3 reveals the results of soil samples from the Ajali Formation: liquid limit (LL) ranges from 21.40 to $27.10 \%$ with a mean value of $24.09 \%$, plastic limit (PL) ranges from 20.80 to $30.30 \%$ with a mean value of $26.79 \%$. The plasticity index (PI) ranges from 0.00 to $5.40 \%$ with a mean value of $2.70 \%$. The optimum moisture content (OMC) and the maximum dry density (MDD) ranges from 6.40 to $10.70 \mathrm{mg} / \mathrm{m}$ with a mean value of $8.47 \mathrm{mg} / \mathrm{m}$ and 1.10 $2.80 \mathrm{mg} / \mathrm{m}$ with a mean value of $1.9 \mathrm{mg} / \mathrm{m}$. The cohesion value obtained varies from 0.20 to $0.41 \mathrm{~kg} / \mathrm{cm}^{2}$ with a mean value of $0.30 \mathrm{~kg} / \mathrm{cm}^{2}$. The shear angle of internal 


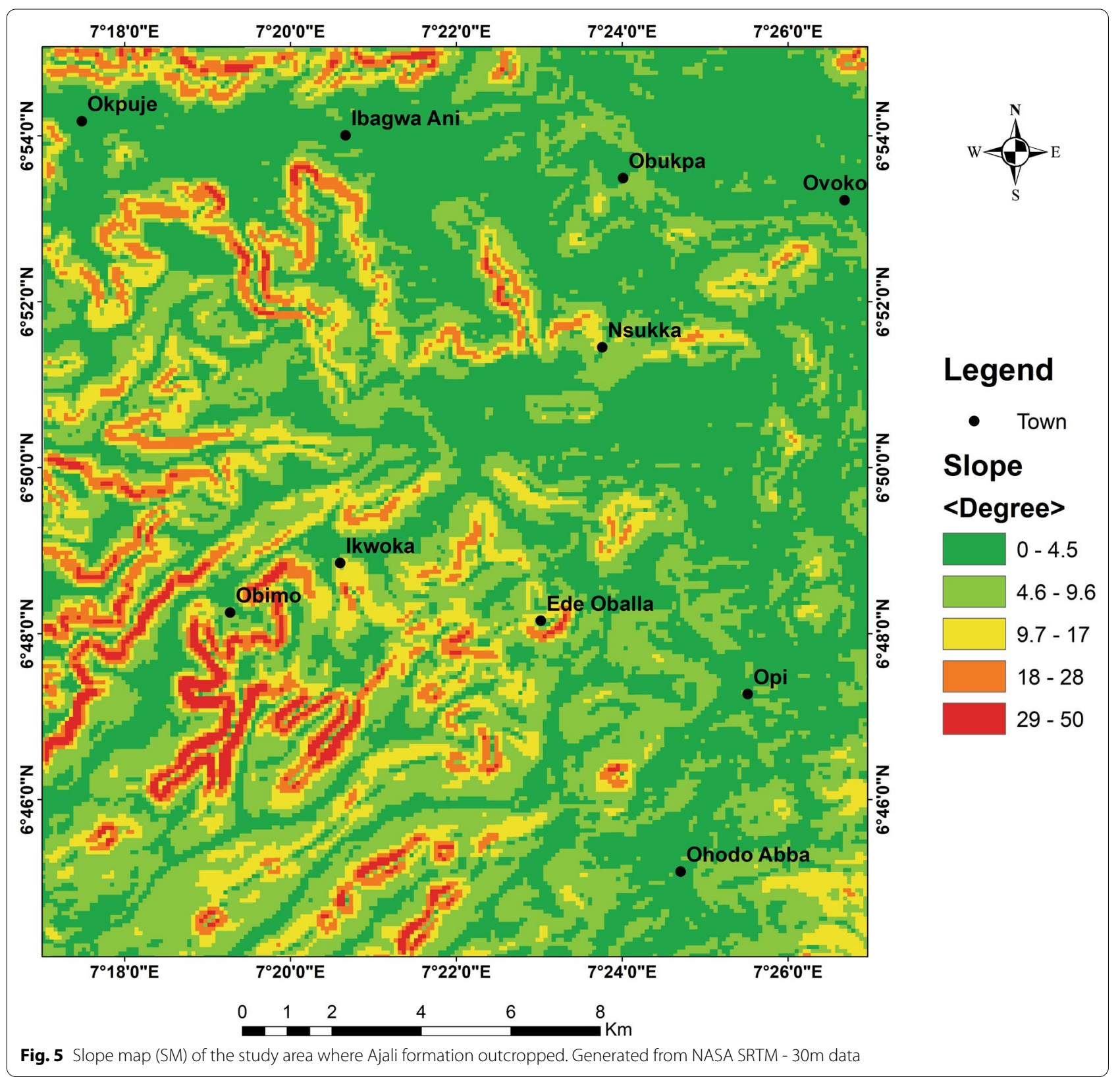

friction ranges from $18.0^{\circ}$ to $30.0^{\circ}$ with an average value of $25.3^{\circ}$. The values obtained for hydraulic conductivity range from $(2.01-3.61) \times 10^{-3} \mathrm{~cm} / \mathrm{s}$ with a mean value of $2.70 \times 10^{-3} \mathrm{~cm} / \mathrm{s}$ suggesting high permeability. The sand and silt contents range from 87.0 to $100.0 \%$ with a mean value of $95.10 \%$ and $0.00-2.60 \%$ with a mean value of $1.43 \%$. The shear strength of the soil is the maximum internal resistance of the soil to the motion of its particles by sliding or slipping. The forces that withstand shear are mainly the inter-granular friction and the cohesion force.
Table 3 shows that the soils of the Ajali Formation exhibit low plasticity, highly sandy with low silt content, low cohesion, very loose compactness, and high permeability. According to Coulomb's law, as described by (Onwuemesi 1990), the shear strength is given by the equation $\mathrm{S}=\mathrm{C}+\tan \theta \mathrm{P}$ where $\mathrm{S}=$ Shear strength, $\mathrm{C}=$ Cohesion, $\mathrm{P}=$ Effective pressure, $\tan \theta=$ Coefficient of friction, and $\theta=$ Angle of internal friction. The vital role played by shear strength is that the friction force due to run-off and the seepage flux is only opposed by the angle of internal 


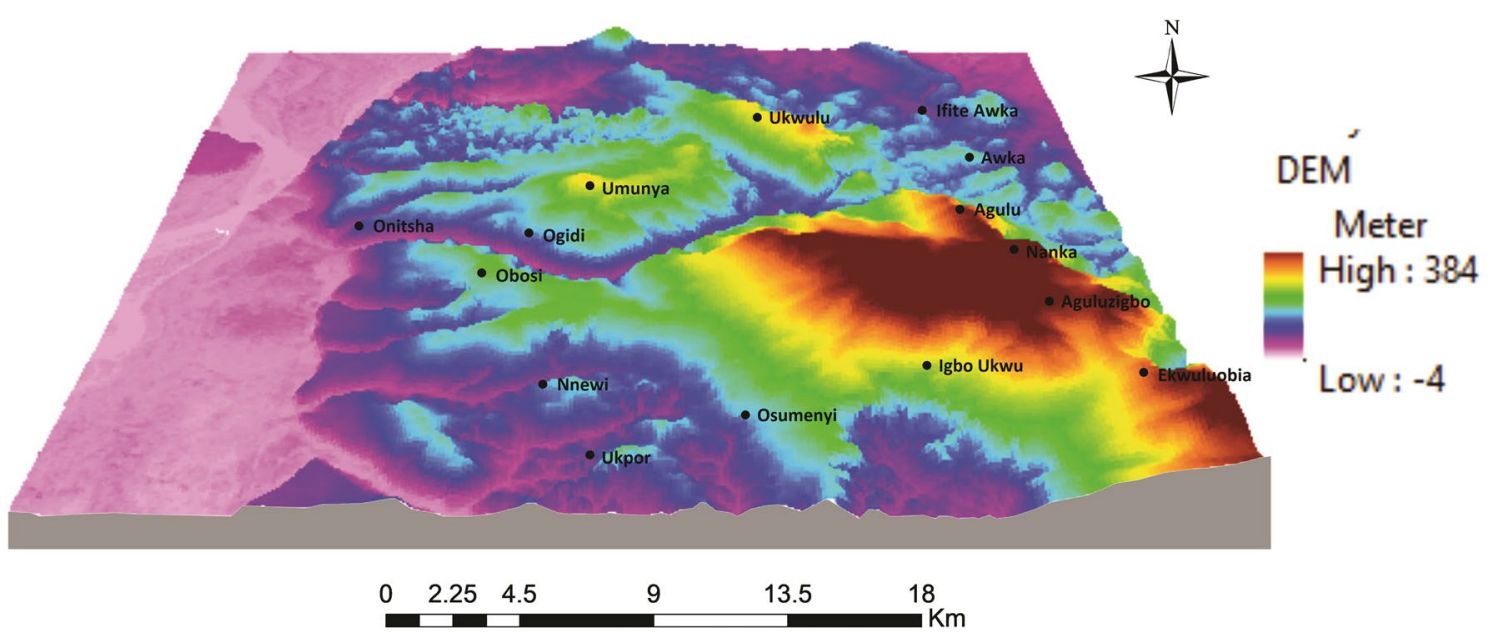

Fig. 6 Digital elevation model (DEM) of the study area where Nanka formation outcropped. Generated from NASA SRTM - 30m data
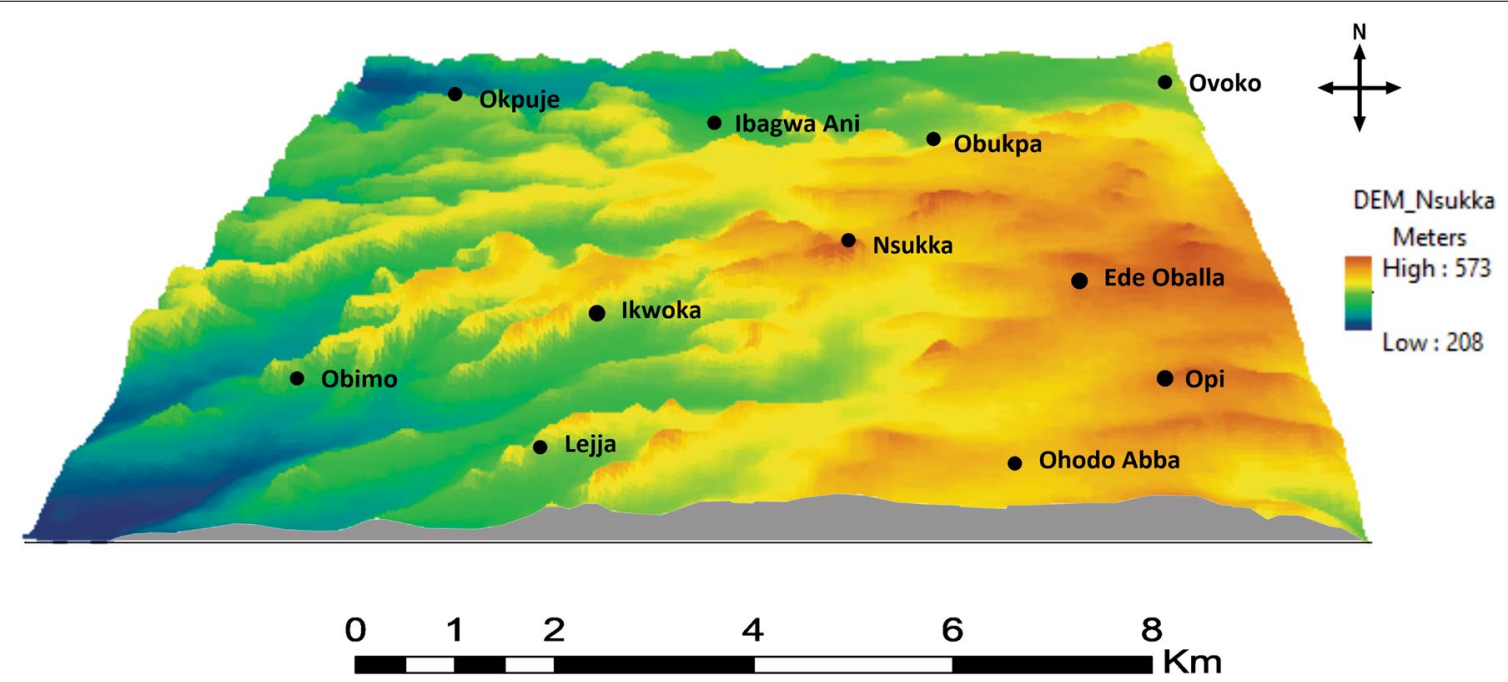

Fig. 7 Digital elevation model (DEM) of the study area where Ajali formation outcropped. Generated from NASA SRTM 30m data

friction because of the very low cohesion to cohesionless and very permeable nature of the sandy formations. Several workers including (Paterson et al. 1978; Sudicky 1987; Onwuemesi 1990) have recorded detailed reports on permeability blueprints of soil samples. Permeability is a measure of the capacity of soil to permit the passage of fluids such as water and it has the dimension of velocity (Onwuemesi 1990). The environmental framework of these study areas which includes ridges and domes impede the infiltration of the rainwater. This rainwater then flows as runoff and loses the soil particles as a result of the very low shear strength of the soil. The lithological and geotechnical characterization of the sedimentary lithologies of Nanka and Ajali Formations shows that the landscape contributed to the initiation of gully erosion disaster in the study areas.

\section{Genesis and continued expansion of gully erosion in the study area}

Different parts of the study areas where the two main sedimentary formations (Nanka and Ajali Formations) cropped out have continued to witness incipient gullies in recent times. The genesis and continued expansion of gully erosion in the area is mainly linked to the geology, topography, human activities that are poorly planned, and geotechnical properties of the soils. The soil surface is also accessible to rainfall and run-off due to scanty vegetation/plant cover in the areas of study. The 


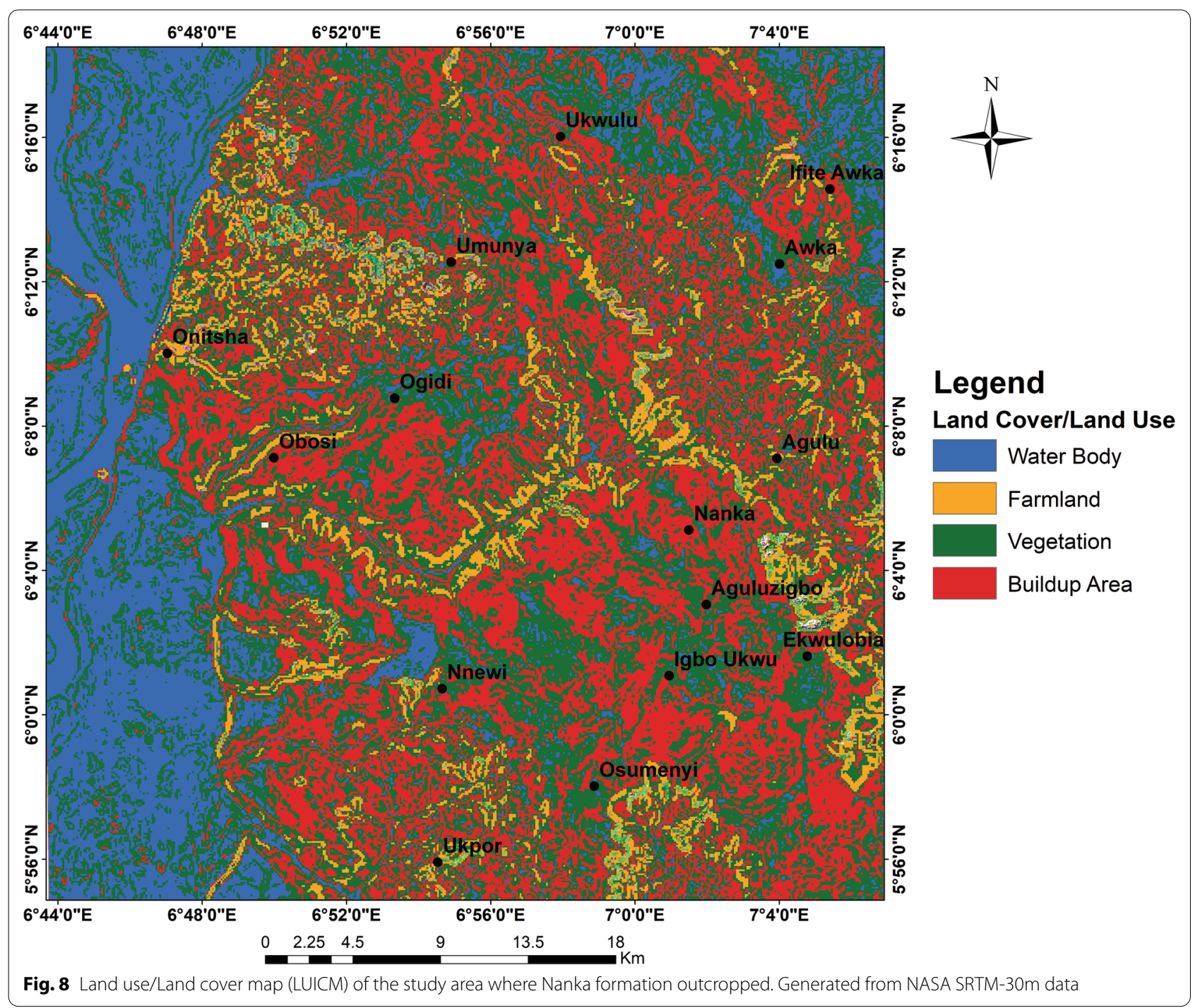

geotechnical properties of these areas determine their susceptibility to gully erosion (gorges) which are advancing into canyon proportions. Detailed mapping, plastic limits, low liquid limit, low plasticity, the high proportion of sands, high permeability, the shear strength, and the very loose compactness of soils from the Nanka Formation and Ajali Formation shows that the geological conditions and geotechnical composition of the soils were responsible for the initiation and propagation of the gully erosion in the study areas. The generated slope maps, digital elevation models, and land cover/land use maps from NASA SRTM 30m data exactly show the influence of slope, elevation, and poor land use/land cover on the genesis and development of gully erosion in the study areas. Low plastic, low cohesive, and very loose compactness of soils are in line with the works of (Onwuemesi 1990) in Nsukka and its environs where Ajali Formation outcropped and (Igwe and Egbueri 2018) in Anambra Basin. The inter-bedded shale in the Nanka Formation changes in volume resulting in alternate wetting and drying thereby enhancing gulling. Also, the interbedded shale increases in volume when wet and becomes sticky and plastic during the rains. This is in line with the considerable study by Egboka et al. (1983, 2019), Egboka and Okpoko (1984), Igwe and Egbueri (2018). Based on the independent studies by Egboka et al. (1983, 2019), Egboka and Okpoko (1984), Igwe and Egbueri (2018) and confirmed by this study, such interbedded shale formed 


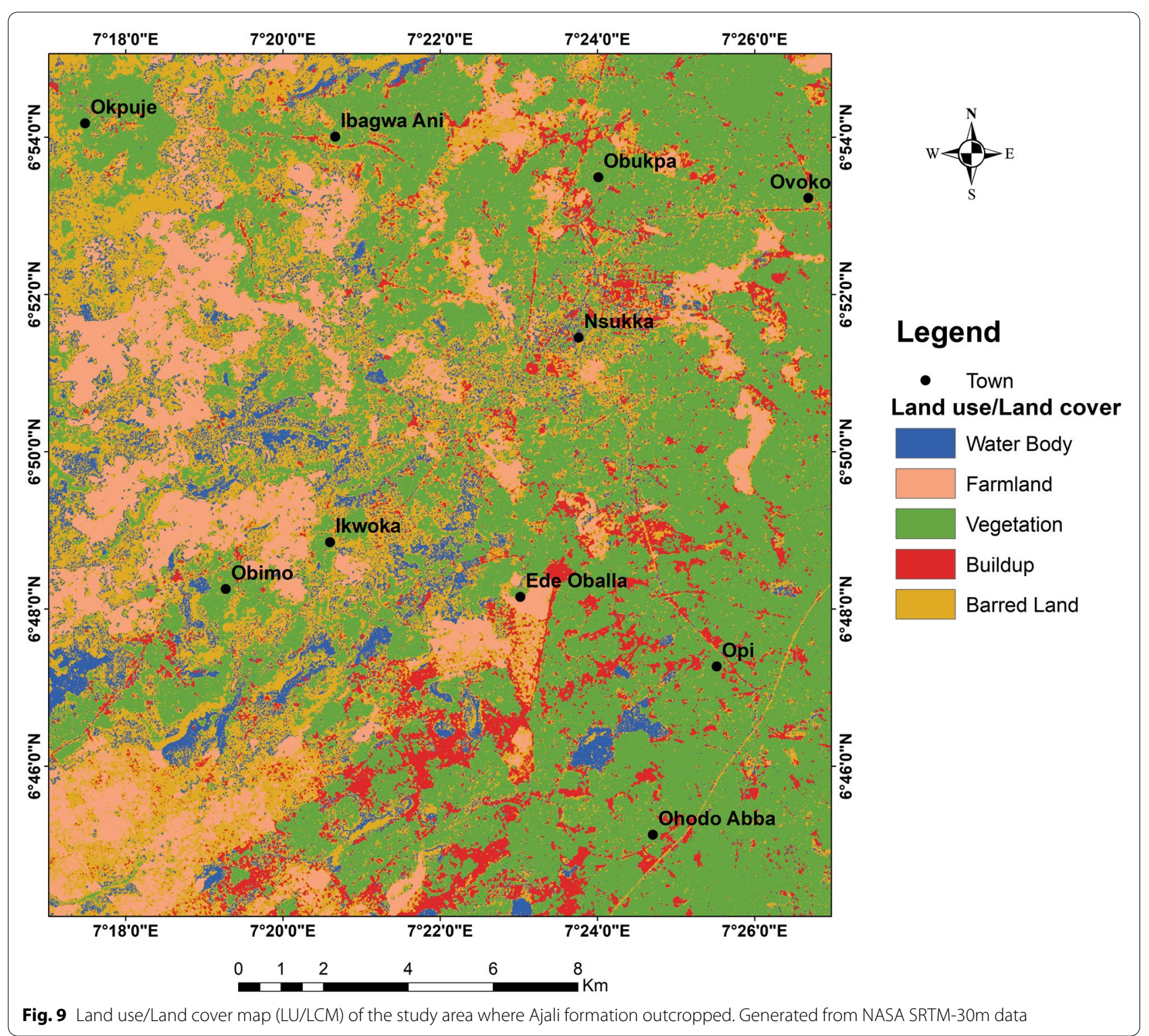

a dry thick layer during the dry season causing contraction of clay and eventually led to soil fracture which is also conveyed to the sandy units. The shale is soaked with water after rainfall; the clay minerals swell up and establish a susceptibility to slide. The thick layers of sand underlain by the plastic shale usually slide down-dip in the gully with the shale acting as a lubricator. The characteristics of the Nanka Formation, rainfall-runoff, long hilly and steepness of the slope, poor land cover, low plasticity, a high proportion of sands, high permeability, the shear strength, loose compactness of soils, and human activities enhanced the initiation and continued expansion of gully erosion in the study area. These features led to carving, piping, and landslide resulting in a step-like gully cross-section (Fig. 10) that is displayed in the majority of the affected areas where the Nanka Formation outcropped. Different colours of the soils ranging from light grey, white, pink in the study area where Ajali Formation outcropped shows different heat-releasing and heat-absorbing capacity of the soils. These reveal the non-co-existence of expansion and contraction of the soils leading to structural damages of the Ajali Formation. The friability of the Ajali Formation, loose structure, low degree of diagenesis, poorly bonded mechanism, low compressive strength, the rapid disintegration of soil during rainfall and run-off, low soil fertilization, long hilly 

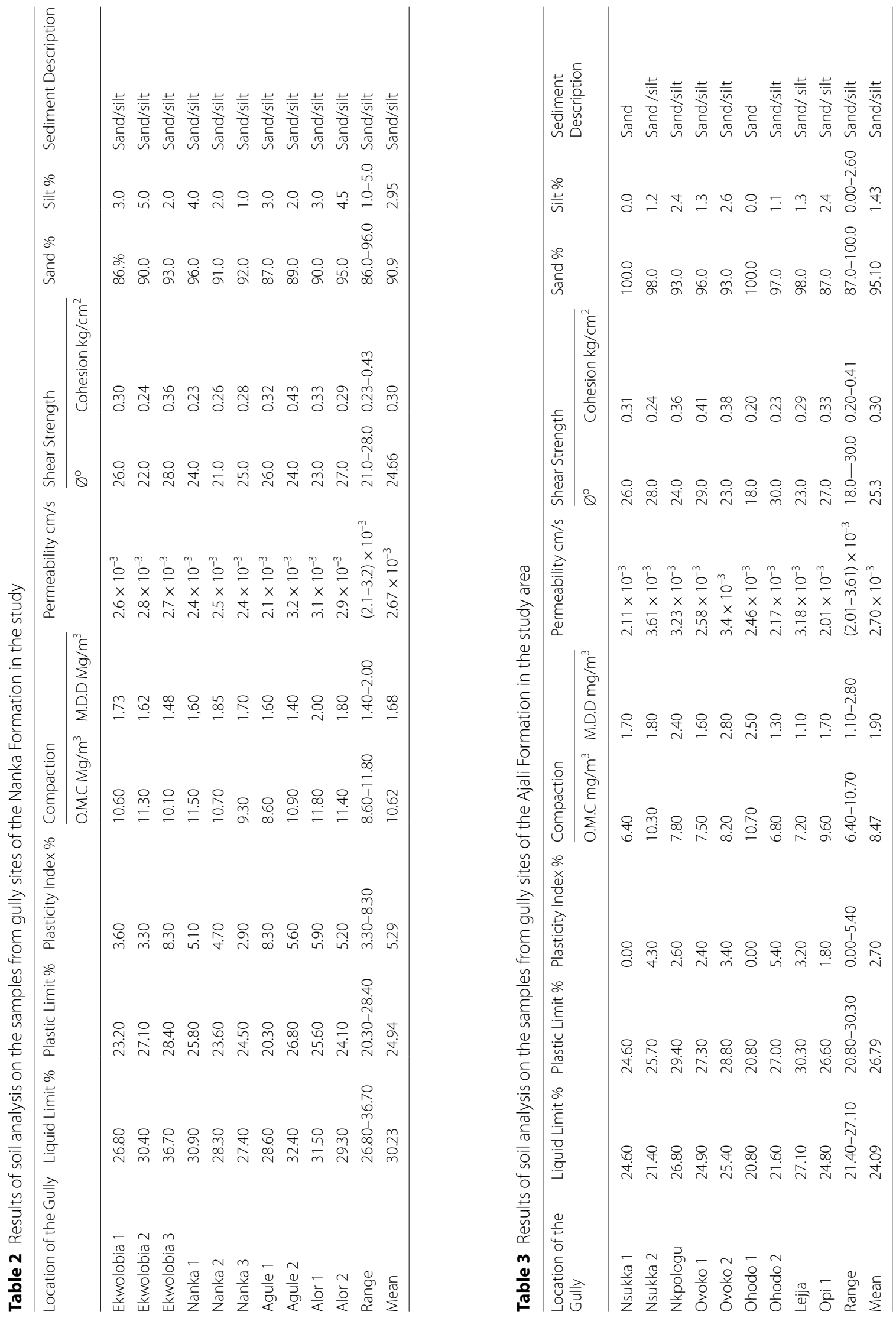


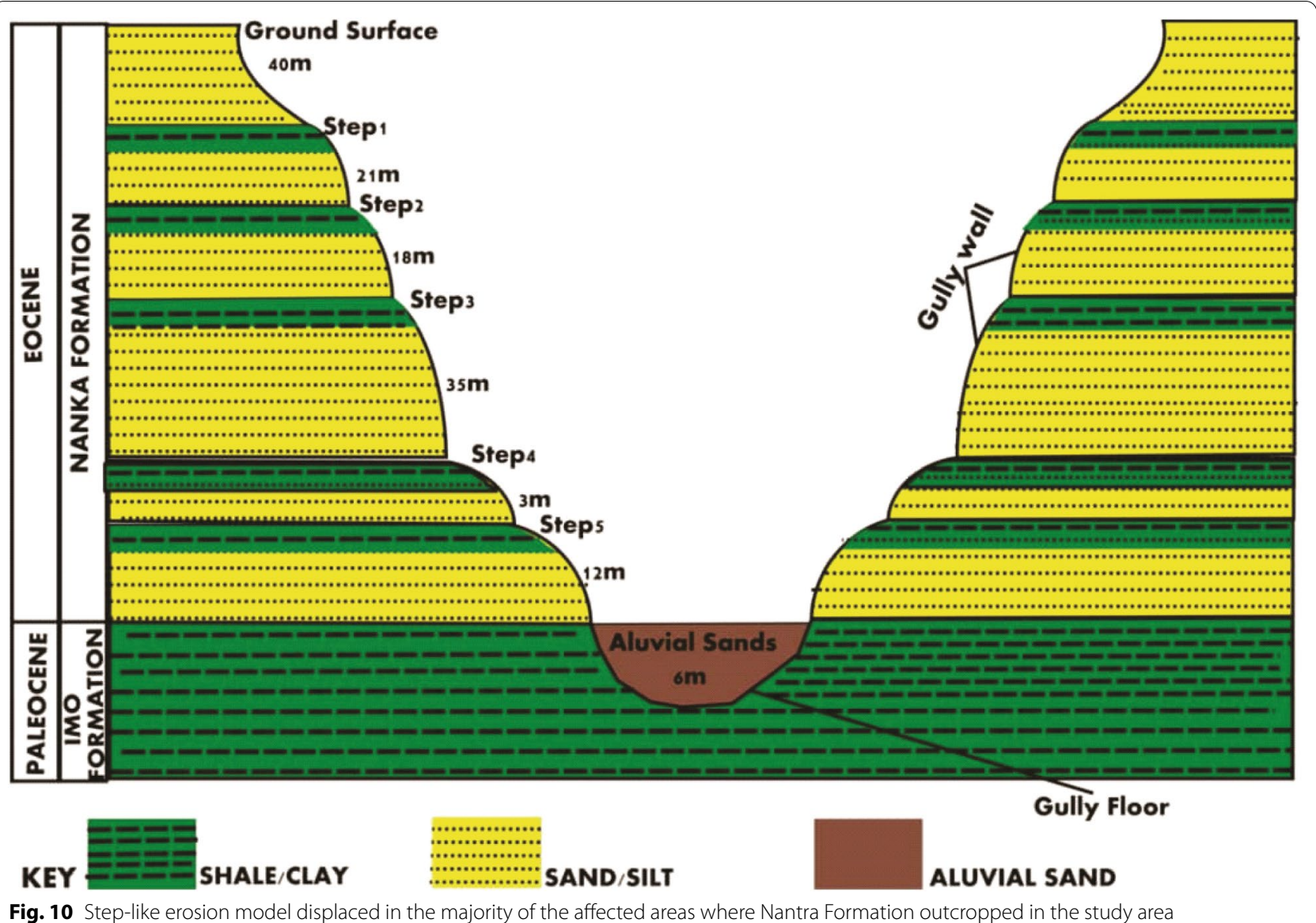

and steepness of the slope, poor land cover, and faulty land usage, low plasticity, a high proportion of sands, high permeability, the shear strength, the very loose compactness of soils, and human activities contributed to initiation and continued gullying erosion expansion. These features result in slumping and sliding movements in the affected areas. A schematic representation of the gullies in the study area shows a convex gully cross-section (Fig. 11). The danger of this badland degradation was found in all the gully sites where gorges are about $3.2 \mathrm{~m}$. The potential implications of these gully erosion include damaging of buildings, residential houses, bridges, and roads, loss of farmland and vegetation, isolation of villages and towns, increased migration of inhabitants as well as degradation of agricultural fertile land.

Following those key findings, agronomic technique through the use of plant cover, soil conservation, contouring, and strip cropping and tillage system should be adopted. These would ensure rainfall absorption which will, in turn, reduce the impact of rainfall on the soil. Also, engineering protections by bundling, contour trenching, terracing, and grassed waterways should as well be adopted. With the engineering protection, slope characteristics of the area will be changed in such a way that the amount and the velocity of runoff will be lowered. The soils will be protected and the surface runoff will be lessening. These practices should be adopted to reclaim the ravaged land and to further discontinue the expansion of other gully erosion potential areas in the study areas.

\section{Conclusions}

This study treated the gully erosion problem, which constitutes a serious threat to several communities in southeastern Nigeria. It is also caused by poorly planned anthropic activities. The lithological and geotechnical characterization of the Nanka and Ajali Formations revealed that the gully erosions were developed on steep slopes and non-vegetated areas. Field surveys and laboratory analyses revealed that the genesis and continued expansion of gullies in the study area was facilitated by the cohesionless and very permeable nature of the sandy formations. The generated slope maps, digital elevation models, and land cover/land use maps from NASA SRTM $30 \mathrm{~m}$ data exactly show the 


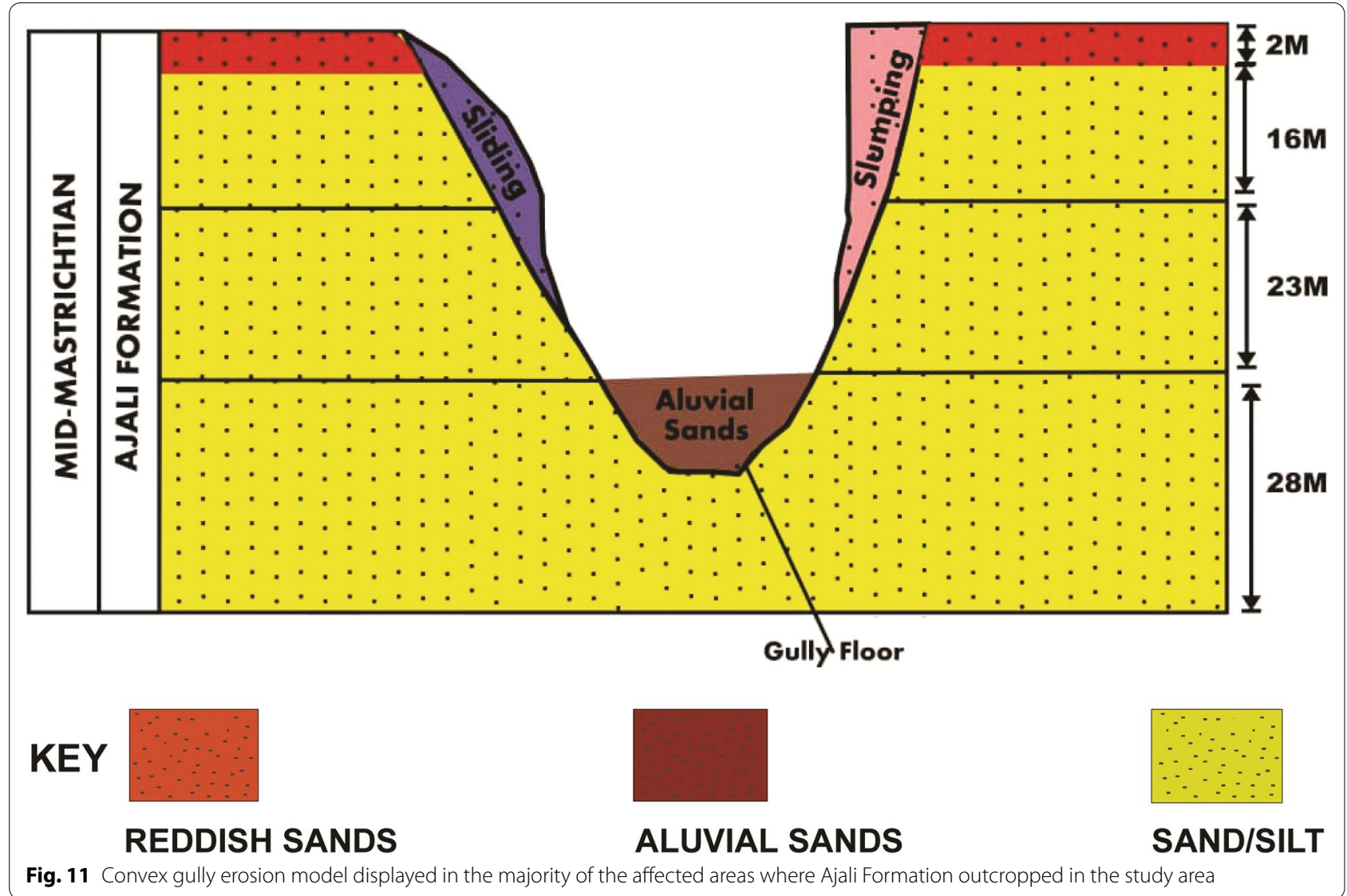

influence of slope, elevation, and poor land use/land cover on the genesis, and development of gully erosion in the study areas. Agronomic and engineering techniques have been proposed which can play mitigating roles in the formations as well as the continued expansion of gully erosion hazard in the study area.

\section{Acknowledgements \\ The support of Ajike Ikechukwu, Stanley Map, and Akunne Samson towards this research work is hereby acknowledged. Our greetings also go to the reviewers of this manuscript for their positive constructive comments and suggestions that have improved the quality of this paper.}

\section{Authors' contributions}

AO: He led the conceptualization, data curation, analysis, investigation, and the original draft of the manuscript. OBO: He supported the conceptualization, data curation, analysis, investigation, and drafting of the manuscript. GOA: He also supported the conceptualization, data curation, analysis, investigation, and drafting of the manuscript. All authors read and approved the final manuscript.

\section{Funding}

This research work did not get any grant from institutions, agencies, or individuals.

Availability of data and materials

Data and materials, generated and analysed are available in this research work.

\section{Declarations}

Ethics approval and consent to participate Not applicable.

\section{Consent for publication}

Not applicable.

\section{Competing interest}

On behalf of all authors, the corresponding author states that there is no conflict of interest among all the authors in this research work.

\section{Author details}

${ }^{1}$ Department of Geological Sciences, Nnamdi Azikiwe University, Awka, Anambra, Nigeria. ${ }^{2}$ Department of Earth Sciences, Federal University of Petroleum Resources, Effurun, Delta, Nigeria. ${ }^{3}$ Department of Geology, Federal University Lokoja, Lokoja, Kogi, Nigeria.

Received: 7 February 2021 Accepted: 11 March 2021

Published online: 23 March 2021

\section{References}

Abdulfatai IA, Okunlola IA, Akande WG, Momoh LO, Ibrahim KO (2014) Review of gully erosion in Nigeria: causes, impacts, and possible solutions. J Geosci Geomat 2(3):125-129

Adeleye DR, Fayose EA (1978) Stratigraphy of the type section of the Awi formation. J Min Geol 15:33-37 
Anejionu O C D, Nwilo P C, Ebinne E S (2013) Long term assessment and mapping of erosion hotspots in Southeastern Nigeria. FlG working week, environment for sustainability Abuja, 19p

Ashiagbor G, Forkuo EK, Laari P, Aebeyir R (2013) Modeling soil erosion using RUSLE and GIS tools. Int J Remote Sens Geosci 2(4):7-17

Brice JC (1966) Erosion and deposition in thin, the loess-mantled great plain, Medicine Creek Drainage Basin, Nebraska. Department of the Interior Geological Survey Professional Papers, Washington, p 352p

British Standard Institution (BS) 1377, (1990) Methods for testing soils for civil engineering purposes. British Standard Institution, London, p 232p

Egboka B C E, Okpoko I E (1984) Gully erosion in the Agulu -Nanka Region of Anambra State, Nigeria. Challenges in African Hydrology and Water Resources (Proceedings of the Harare Symposium), IAS Publisher, 144: 335-347

Egboka BCE, Orajaka IP, Ozor P (1983) Sulphur and iron geochemistry as a causation factor of erosion and gullying at Agulu-Nanka-Oraukwu gullies. Anambra State, Nigeria

Egboka BCE, Orji AE, Nwankwoala HO (2019) Gully Erosion and landslides in southeastern Nigeria: causes, consequences and control measures. Global J Eng Sci 2(4):11 p. https://doi.org/10.33552/GJES.2019.02. 000541

Ezemonye MN, Emeribe CN (2012) Rainfall erosivity in Southeastern Nigeria. Ethiop J Environ Stud Manag 5(2):122-129

Fernandez C, McCool WuJ, Stockle C (2003) Estimating water erosion and sediment yield with RUSLE and SEDD. J Soil Water Conserv 58(3):128-136

Gayen A, Bai S (2019) Gully erosion susceptibility assessment and management of hazard-prone areas in India using different machine learning algorithms. Sci Total Environ 668:124-138. https://doi.org/10.1016/j.scito tenv.2019.02.436

Geleta H I. (2011) Watershed sediments yield modelling for the data-scarce area. Ph. D. Dissertation, University of Stuttgart, Stuttgart, 240p

Hoque M, Ezepue MC (1977) Petrology and paleogeography of the Ajali Sandstone. J Mining Geol 14(1):16-22

Igwe C A (2012) Gully erosion in southeastern Nigeria: role of soil properties and environmental factors. In: Research on soil erosion, 13p. DOl: https:// doi.org/10.5772/51020

Igwe O (2015) Predisposing factors and the mechanisms of rainfall-induced slope movementsin Ugwueme, South-East Nigeria. Bull Eng Geol Environ. https://doi.org/10.1007/s10064-015-0767-0

Igwe O, Egbueri JC (2018) The characteristics and the erodibility potentials of soils from different geologic formations in Anambra Basin, southeastern Nigeria. J Geol Soc India 92:471-478

Iloeje NP (1981) A New Geography of Nigeria. Longman Publishers, Nigeria, p $200 p$

Ionita I (2006) Gully development in the Moldavian Plateau of Romania. Catana 68(3):133-140.

Ishaque F, Hoque MN, Rashid MA (2010) Determination of plastic limit of some selected soils using the rolling device. Progress Agric 21 (1 \& 2):187-194

Ismaiel IAH (2018) Geotechnical investigation and assessment of earthquake factors at Hurghada City, Red Sea Egypt. World Environ 8(3):63-70. https://doi.org/10.5923/j.env.20180803.01

Monkhouse FJ, Small JA (1978) Dictionary of the natural environment. Arnold, London, $\mathrm{p} 2$

Munch JH, Douglas RW (1985) Equipment and methodology of sampling and testing cohesionless sediments. Ground Water Monit Rev 1:38-42
Nwajide SC (1977) Sedimentology and stratigraphy of the Nanka Sand. Thesis, Department of Geology, University of Nigeria, Nsukka, M. Phil

Nwajide CS (2013) Geology of Nigeria sedimentary basins. CSS Bookshops Limited, Lagos, p 565p

Obi G C (2000) Depositional model for the Campanian-Maastrichtian Anambra Basin, Southern Nigeria. Unpublished PhD. Thesis, University of Nigeria, Nsukka, 291p

Obi GC, Okogbue CO (2004) Sedimentary response to tectonism in the Campanian-Maastrichtian Anambra Basin succession, Southeastern Nigeria. J Afr Earth Sci 38:99-108

Obi GC, Okogbue CO, Nwajide CS (2001) Evolution of Enugu Cuesta: A tectonically driven erosional process. Global J Pure Appl Sci 7:321-330

Obiadi II, Nwosu CM, Ajaegwu NE, Anakwuba EK, Onuigbo NE, Akpononu EO, Ezim OE (2014) Gully erosion in Anambra State Southeast Nigeria: Issues and solution. IJES 2(2):796-804

Ojukwu O (2018) Over 2800 erosion sites threatening Southeastern Nigeria. https://sunnewsonline.com/National

Okengwo ON, Okeke OC, Okereke CN, Paschal A (2015) Geological and geological studies of gully erosion at Ekwulobia, Oko and Nanka Towns, Southeastern Nigeria. EJGE 20:113-122

Online document (https://geographyfieldwork.com/slopes)

Onwuemesi AG (1990) Hydrogeophysical and geotechnical investigations of the Ajali Sandstone in Nsukka and environs with reference to groundwater resources and gully erosion problems. J Nigeria Assoc Hydrogeol 2(1):70-76

Paterson RJ, Frape SK, Dykes LS, McLeod RA (1978) A coring and squeezing technique for the detailed study of subsurface water chemistry. Can J Earth Sci 15(1):162-169

Payne PCJ, Fountaine ER (1952) A field method of measuring the shear strength of soils. J Soil Sci 3(1):136-148

Reyment RA (1965) Aspects of the geology of Nigeria. Ibadan University Press Ibadan, Nigeria, p 145p

Simpson A (1954) The Nigerian coalfields The geology of parts of Onitsha, Owerri and Benue province. Geol Surv Nigeria Bull 24:85

Sohne W (1953) Reibung and fohasion bei neo Ackerboden (friction and cohesion of agricultural soils). Grundiland tech 5:64p

Subash T, Vincent P, Nalanth N (2016) Geotechnical assessment of soil in erosion prone-zone. Int J Civil Eng Technol 7(6):227-240

Sudicky E (1987) A natural gradient experiment on solute transport in sand aquifers: spatial variability of hydraulic conductivity and its role in the dispersion process. Water-Resources Investigations Report. http://cfpub. epa.gov/si/si_public_comments.cfm

Surendra R, Sajeev KB (2017) Roles of geotechnical properties of soils on civil engineering structures. Resourc Environ 7(4):103-109. https://doi.org/10. 5923/j.re.20170704.03

Tattam CM (1944) A review of Nigerian stratigraphy. Geol Surv Nigeria Special Report 6:27-46

van Ouwerkerk C, Schakel P (1967) Apparatus for measuring shear strength in the site. J Agric Eng Res 12(1):66-70

\section{Publisher's Note}

Springer Nature remains neutral with regard to jurisdictional claims in published maps and institutional affiliations. 